UDK 351.78:355.48

DOI https://doi.org/10.18485/fb_ic4hs.2018.1

\title{
PROBLEMS OF HUMAN SECURITY IN THE CONTEXT OF HYBRID AGGRESSION
}

\author{
Konstantin N. LOBANOV*, Boris N. SELIN**
}

\begin{abstract}
Transformation of technologies and specific character of social, economic and political conditions of the world community development influence the ways and features of contemporary geopolitical confrontation. In conditions of inevitable threat of global war it has become necessary to use other means that have not caused negative global consequences and that are aimed to resolve emerging contradictions on the world stage. A hybrid warfare or aggression has become a means by which combined, integrated military, political, economic, ideological and psychological measures could be confronted in the form of low-intensity and even latent conflicts. The most important component of the hybrid aggression is a psychological warfare, which involves the conduct of cyber-media and -psychological attacks, propaganda, etc. with the aim to suppress the psychological ability of an object of aggression to resist in case of armed conflict resolution scenario. The main tasks of the hybrid aggression include the creation of nervous and non-spiritual environment in society, immersion in the state of permanent social and political confrontation, destruction of the state authority, initiation of mass protest actions and street riots. Taking into consideration that hybrid aggressions implement brand new IT resources and suitable technologies, firstly, to cover mass audience, secondly, to impact on people's consciousness and subconsciousness, thirdly, to manage and manipulate the motivation and behaviour of large groups of people, this can pose a real threat to public and national security, to physical and mental health and life of citizens of those countries which are subjected to hybrid attacks. All aims, tasks and means of hybrid aggression mentioned above have already been tested and implemented on vast Eurasian and post-Soviet territories. The current article aims to investigate issues concerning protection of people from external hybrid aggression and addresses challenges of ensuring a comprehensive response to these threats.
\end{abstract}

* Doctor of Political Sciences, Belgorod Law Institute of the Ministry of the Interior of Russia named after I.D. Putilin, lobanov.politika@gmail.com

** Associate Professor, PhD, Belgorod Law Institute of the Ministry of the Interior of Russia named after I.D. Putilin, selin-boris@yandex.ru 
Keywords: human security, physical and mental health of people, threat to human security, hybrid aggression, national state security system

\section{INTRODUCTION}

In modern realities, for all subjects of social activity - an individual, society and the State, the problem of ensuring safe existence and development requires special urgency. First of all, this is connected with the negative impact of the globalisation phenomenon on the livelihood of these subjects which has deep objective foundations. The globalisation as a process of global integration and unification, which originates from informational, financial and economic spheres, has captured rather quickly the scope of public relations and institutions and then inflicted their erosion. States have begun to lose a significant part of their sovereignty and to delegate it in favour of other supra-national actors, social organisation of a society has become deprived of its traditional grounds and acquired more and more internationalised character and, finally, the persons who lost their habitual political and social environment have become more vulnerable than ever before. Another crucial factor for the security of all actors of social life in the era of globalisation has been the surge of armed and non-armed violence in the world, caused by the escalation of regional and global geoeconomic and geopolitical competition. The former system of international relations with its mechanisms of checks and balances has collapsed, and the factor of force and dictate has become decisive in world politics. Since the end of 'the Cold War' there has been a multiple increase in armed conflicts with at least 35 million people killed (Сытник, 2012). As a result, the safe space of a human becomes more and more limited and this problem requires an adequate reflection and response.

\section{TRANSFORMATION OF VIOLENCE AND AGGRESSION IN THE MODERN WORLD}

Military conflicts in the era of globalisation have significantly evolved in terms of content and forms of conduct. Thus, the conflict interaction does not mean an immediate destruction or suppression of an enemy in the course of direct encounter, but rather activation and management of development of internal mechanisms of self-destruction. In this case, the use of physical weapons is not necessary as the conflict involves an entire arsenal of destructive influence on the opposing side (Hoffman, 2009). Violence and aggression in conflicts are carried out in the form of combined application of the means of economic, political, technological, ideological, psychological and other influences on the sensitive objects of an opponent - the state system, fundamentals of social structure, physical and psychological wellbeing of population (McCuen, 2008). The new tactic of aggression is called a 'hybrid warfare' and has been used since that time with high efficiency. Since 1989, no less than 25 attempts of using hybrid technologies in internal and external conflicts have been recorded, 13 of which have been successfully completed (Lobanov and Selin, 2017).

The most common variation of hybrid aggression is a 'colour' revolution whose main target is to undermine the system of state power in a particular country implementing a combination of means used to influence consciousness and to control behaviour of population (Luttwak, 1968; Sharp, 2005). Such way of dealing with unfavourable political 
regimes is widely employed by the USA in order to implement its global project of a monopolar world order (Brzezinski, 1997).

\section{MECHANISMS OF HYBRID AGGRESSION AND THEIR EXPRESSION DURING 'COLOUR' REVOLUTIONS}

The implementation of hybrid technologies is stipulated by certain logical actions which are sufficiently described in literature (Luttwak, 1968; Helvey, 2004; Sharp, 2005; Гапич и Лушников, 2010). Let's illustrate this process on the example of the next 'colour' project that was prepared and accomplished in Armenia in 2018 by the collective West headed by the United States. Since the beginning of 2010 this Transcaucasian Republic has been the stage where the latent programme of the national security destruction has been activated. With the support of the US State Department and the US Embassy in Armenia (one of the world's most numerous) ${ }^{1}$, specially trained personnel were promoted to various positions in civil authorities and law enforcement agencies (Григорян, 2018). Majority of these officials have already had some connections abroad ${ }^{2}$, while the others, as a rule, have been motivated financially.

When the number of latent and real oppositionists in the state apparatus increased enough to be able to disrupt the functioning of power institutions and, above all, those that provided protection of the state order, open and mass subjects of protest became the focus of the case. In Armenia this role was performed by the "Elk" ("Exit") party that initiated a series of continues rallies in March-April 2018 with the demand for the Government's resignation. From the very beginning, this small party positioned itself as the protest avant-garde and developed a vigorous activity to involve the population in opposition activities (Григорян, 2018). With the help of populism schemes and new information technologies (the Internet, telephony, social networks), the "Elk" party and its leader N. Pashinyan managed, within a few days, to gather large groups of people dissatisfied with the government policy and to bring them to the anti-regime meetings and protest marches (Гасанов, 2018). Actually, the official authorities, having lost reliable support in the republican Government and Parliament, didn't decide to use adequate measures in order to protect constitutional orde and they were practically paralysed and helpless in the face of irritated population skilfully managed by the opposition and its foreign coordinators. The hybrid aggression implemented in Armenia has resulted in the change of elites, the reversal of foreign policy of the country towards the Western world, economic crisis and permanent political turbulence.

${ }^{1}$ With the population of Armenia estimated to be about 3 million, the official staff the US Embassy in this Republic comprise 1200 members, i.e. 1 employee accounts for 2500 citizens, which once again emphasises the exceptional importance of this Transcaucasian republic in the US geopolitical calculations.

${ }^{2}$ For example, all 23 members of the new Government of Armenia, who came to power in May 2018, were educated or worked in state authorities, public organisations, private companies abroad, mainly in the USA. See: Сафарьян, А. (2018). Новые министры Пашиняна: кто они? Sputnik Армения. https://ru.armeniasputnik.am/review/20180513/12001323/novye-ministrypashinyana-kto-oni.html 20/08/2018. 


\section{HYBRID AGGRESSION AND HUMAN SECURITY THREATS}

Analysing the effects of hybrid aggressions on state and public security, it's impossible not to notice the effects that these aggressions have on the security of an individual. In literature, this phenomenon of individual security is described as a human condition when the action of external and internal factors doesn't lead to a poor state, to deterioration of the functioning and development of physique, consciousness, mentality and a human in general, and doesn't prevent him or her to achieve certain desirable purposes (Заплатинський, 2012). On the contrary, it is possible to acknowledge, that hybrid technologies as a set of aggressive, opposing to normal physical and psychological event of the individual factors, comprise harm to such event, since assume conscious deprivation or threat of deprivation of life of people, destruction of consciousness and pressure on psyche. Hybrid aggression combines different forms of armed and non-armed violence and, therefore, it poses an inevitable danger for human life. 'Colour' revolutions have been accompanied by mass riots, rampart crime, provocations, assassinations of leaders, consumer and food famine, and have often resulted in peoples' deaths3, and the overwhelming mass of the population have significantly suffered a declining in living standards. It is necessary to recognise that in many countries that have undergone hybrid aggression, a large proportion of citizens have neglected the danger to their lives in their willingness to support the destructive opposition by assisting in the confrontation with the authorities, as it was observed, for example, in Armenia and Ukraine.

Such temporary symbiosis of the peaceful population and rival opposition can be explained only by one thing - the 'colour' revolutions had been made in people's minds long before street protests. People's consciousness was transcoded into desirable direction and they began to act in accordance with new stereotypes and patterns of behaviour. Therefore, the psychological warfare as the most important component of the hybrid aggression was put into effect in order to achieve such a result (Sharp, 2005). With the help of modern information and communication technologies, the means of such warfare have been significantly improved in recent decades. Thus, the Internet and social networks make possible an on-line broadcasting of ideological content and engage in 'brainwashing' of a huge audience. The networks give also an opportunity to control this zombied part of the audience and using simple technologies of network marketing to gather quickly people in mobile teams with the aim of setting up protest marches under guidance of team coordinators (so-called 'beacons').

The process of this psychological manipulation aims to commit severe violent actions against the inner world of a person: suppression of the ability of critical thinking and of analysing the events, delaying the mechanism of self-control of his or her own actions, disabling the congenital reflexes of self-preservation. In such a state people can easily turn into an object of manipulation from outside, and this opportunity, in our opinion, is the major challenge to the security of a human. So, this threat should not be underestimated as the outcome of the struggle for minds, for the inner world of a person determines largely

3 During the "Maidan" revolution in Ukraine, 77 civilians and 12 law enforcers were massacred. The mass death of people was used by the "Euromaidan" facilitators to foster the coup d'état. 
the success or failure of implementing the attempts of hybrid aggression in a particular country.

\section{PROVISION OF HUMAN SECURITY IN THE CONTEXT OF HYBRID AGGRESSION}

Nowadays, the autarchy of physical space and especially the inner world of a person is not possible by definition, therefore, no one, even the most perfect state system is able to reach an absolute level of safety of population. Open borders and the universal access to information resources make citizens of any country vulnerable to external influence. In addition, hybrid aggression is not among the internal chronic threats to human security (famine, diseases), which the public and state system of each country are more or less ready to resist. This type of aggression represents the so-called sudden and painful change, the adequate reaction to which from the part of society and the State is less predetermined and depends on the set of certain conditions (Белов, 2012).

Thus, in order to fight effectively against a hybrid aggression launched from the outside, it is important to acquire: firstly, sufficient resources to establish and enable normal functioning of the national security system; secondly, stability of economic and political systems, diminishing the reasons for internal conflicts in communities; thirdly, high level of stress resistance of state and social systems to withstand extreme and crisis situations; fourthly, made up and nationwide implemented set of measures aimed to protect and maintain the physical and mental health of the nation, which in its turn is the most essential requirement of its civil condition.

The combination of all the above-mentioned terms would obviously represent a reference sample which in real practice is elusive even for the developing democracies of the Eurasian and post-Soviet states region. However, these countries must be anxious to achieve and maintain an acceptable level of security for their society, the State and an individual, that, in the face of increased risks and threats to global development, is an equivalent to their survival.

\section{CONCLUSION}

a) The age of globalisation increases risks and threats to human security significantly, and the security space itself is becoming drastically limited;

b) Conventional physical violence, used for the resolution of social contradictions during previous times, is now giving way to new improved methods of conflict interaction;

c) Hybrid aggression as a combination of different and mostly non-armed ways of pressure is widely used by the collective West headed by the United States against unfavourable political regimes in the Eurasian and post-Soviet states region in the course of the socalled 'colour' revolutions;

d) An important component of hybrid technologies is the psychological warfare, which is carried out with the help of new information technologies (the Internet, telephony, social networks) and is aimed to change the consciousness and behaviour of large masses of a community by force; 
e) The hybrid aggression is targeted to harm physical and mental health of a person as far as it is based on violent infringement of rights and personal freedom of people, it means an aggressive interference in the nature and inner world of an individual with the purpose of mindset manipulation and actions for the sake of political benefits;

f) In order to neutralise the potential and real threats and risks to human security emanating from the hybrid aggression acting from the outside, the society and the State need to build and maintain a system that will be able to provide the national security - a set of economic, political, social, military, legal, informational, health means, forces and conditions guaranteeing normal functioning of community and providing its members with the protection from external and internal cataclysms.

\section{REFERENCES}

Белов, С.В. (2002). Основные понятия, термины и определения в безопасности жизнедеятельности. Безопасность жизнедеятельности, 2, 37-40; 3, 37-43.

Brzezinski, Z.K. (1997). The Grand Chessboard: American Primacy and Its Geostrategic Imperatives. Published by Basic Books, A Member of the Perseus Books Group.

Гапич, А.Э., Лушников, Д.А. (2010). Технологии «цветных революций». РИОР.

Гасанов, К. (2018). «Бархатная революция» в Армении: Пашинян победил. Что дальше? Царьград. https://tsargrad.tv/articles/barhatnaja-revoljucija-v-armeniipashinjan-pobedil-chto-dalshe_130673 21/08/2018.

Григорян, С.Г. (2018). Армянская «бархатная» революция. Эдит Принт.

Helvey, R.L. (2004). On Strategic Nonviolent Conflict: Thinking About the Fundamentals. Albert Einstein Institution.

Hoffman, G.F. (2009). Hybrid Warfare and Challenges. Joint Force Quarterly, 52, 34-48.

Заплатинський, В.М. (2012). Логіко-детермінантні підходи до розуміння поняття «Безпека». Вісник Камянець-Подільського національного університету імені Івана Огієнка. Фізичне виховання, спорт і здоровя людини, 5, 90-98.

Lobanov, K.N., Selin, B.N. (2017, November). Hybrid and «colour» technologies as a threat to the national security. In Proceedings of the POKO 2017 scientific conference «Impact of Changes in Operational Environment on Preparation and Execution (Design) of Operations» (pp. 293-307).

Luttwak, E.N. (1968). Coup d'Etat: a Practical Handbook. The Pinguin Press.

McCuen, J.J. (2008). Hybrid Wars. Military Review, 88 (2), 107-113.

Сафарьян, А. (2018). Новые министры Пашиняна: кто они? Sputnik Армения. https://ru.armeniasputnik.am/review/20180513/12001323/novye-ministrypashinyana-kto-oni.html 20/08/2018.

Sharp, G. (2005). From Dictatorship to Democracy A Conceptual Framework for Liberation. Albert Einstein Institution.

Сытник, Г.П. (2012). Государственное управление в сфере национальной безопасности. Русское слово, 40. 